FELIPE VANDER VeLDEN

Universidade Federal de São Carlos (Brazil)

\title{
Things that white men have in great quantity: Chickens and other exotic birds among Karitiana (Rondônia, Brazilian Amazon)
}

\begin{abstract}
A lthough some anthropological and ethnobiological studies have focused on native Amazonian or lowland South American peoples' knowledge of (and relationships with) the immense diversity of native bird species in the wild (Crocker 1985; Jensen 1988; Gianini 1991; Reina \& Kensinger 1991; Belaunde 1994; Walker 2010; Imopec 2011; Martinez Mauri 2014; Pino Benitez 2014; Nemo et al. 2017; Sanchez 2019), very little is known about the interactions between these societies and bird species introduced after contact with non-Indians, whether domesticated (chickens, ducks, turkeys) or exotic or invasive wild species (such as pigeons and herons). I believe that the same can be said about ethnoornithology studies set in different ethnographic contexts on other continents, which generally focus on native wild birds, and pay little or no attention to simple and ubiquitous species like chickens and other common domestic birds. The same is true even when scholars investigate native birds raised as pets or in captivity (Bulmer 1967; Hunn 1977; Majnep \& Bulmer 1977; Nelson 1983; important exceptions are Forth 2004: 39-40, 89-90; Jernigan 2016; Bonta 2008; Tidemann \& Gosler 2010; Anderson 2016; Forth 2016 ; Jernigan 2016).

Perhaps ethnological research addressing domestic or household animals (i.e, those living alongside human groups) is scarce because of what Joanna Overing (2003: 297-298) dubbed the "anthropological lack of regard for domesticity and the everyday". It is true that compared with the spectacular richness and beauty of avian fauna in the Amazon, hens do not seem the most thought-provoking topic, even after Clifford Geertz demonstrated (1973), in his famous essay about
\end{abstract}


Balinese cockfights, that focusing on something routine and banal (like roosters) can open up in-depth insights and understanding of a culture. The way the Karitiana's deal with domesticated birds reveal some of their relationships with other beings present in their world, such as white people, whom they call opok and who have become a permanent presence in the daily life of this indigenous group. Furthermore, by observing the birds and other new animals, we can shed light on some of the obstacles to various animal raising projects promoted as solutions to problems related to issues of economy, food safety and sovereignty within Brazil's indigenous communities.

The Karitiana currently number approximately 315 people (Sesai 2014) spread over five villages, all located in the municipality of Porto Velho, the capital of the state of Rondônia in the Brazilian Amazon. They speak the only extant language of the Arikém family, which belongs to the Tupian linguistic stock. Historical reports indicate that the Karitiana may have originated in an area slightly southeast of their present location and were subsequently pushed northwest as Brazilian expansionist efforts began to affect the region in the second half of the nineteenth century, only to gain momentum in the mid-twentieth century (Vander Velden 2014). The first written reference to this group ("Caritianas") dates from 1907, when Marshal Cândido Rondon ${ }^{2}$ heard of their presence on the banks of the Candeias and Massangana Rivers (the latter is a tributary of the Jamari) (Rondon 1907: 329). Later, the group entered into contact with the surrounding society, and was finally located and settled by $\mathrm{FUNAI}^{3}$ indigenists in 1969 on the banks of the igarapé Sapoti (Sapoti Creek, a tributary of the Rio das Garças, which flows into the Candeias River). This first settlement became permanent and moved slightly to the west, to where Kyõwã or the Central Karitiana village is now located; this is the largest, oldest, and most central village in the Karitiana indigenous territory (Terra Indígena Karitiana), covering roughly 89,000 hectares which were officially recognized and demarcated in 1986 . Over the last fifteen years the group has begun to scatter across its traditional territory, in order to recover large areas from which they had been expelled from in the early twentieth century and which were ignored in the demarcation of official indigenous land. During this process of dispersion, two villages were erected outside the zone officially demarcated by the Brazilian government.

The recognized Karitiana territory is almost entirely covered with intact forest, except for the areas occupied by the villages, gardens, and old capoeiras (cleared land formerly used for planting and dwellings). Forest cover in the vicinity of villages outside the indigenous territory is more irregular, but there are still large tracts of native green cover in the vicinity (especially in the Candeias River Basin). The Karitiana define themselves as hunters, and while the group

\footnotetext{
${ }^{1}$ This is the official count, but there are reports that the Karitiana population has already surpassed 400 (Íris Araújo, personal communication, 2019).

${ }^{2}$ The founder of modern Brazilian indigenism and a national hero in Brazil.

${ }^{3}$ Fundação Nacional do Índio (National Indian Foundation), the Brazilian federal agency tasked with protecting Indigenous communities.
} 
still obtains most of its resources from fishing and farming (cassava, maize, beans, rice, peanuts, coffee, and various types of fruit), they are increasingly dependent on money from jobs in the cities of the regions, pensions, and Brazilian government's social programs, with allows them to purchase much of what they need in the markets and fairs of Porto Velho and the surrounding region.

\section{The Karitiana villages}

My research was mainly carried out in two Karitiana villages, Kyõwã and Byyjyty ot'soop aky, located in the municipality of Porto Velho. Kyõwã (literally "village [ky] child" [õwã], i.e. "new village") is the oldest of the five Karitiana villages that exist today and is located nearly in the center of the Karitiana indigenous territory, on the banks of the Sapoti Creek. It is also known as Central Village or New Village, and in 2015 had an approximate population of 250. Kyōwã is located in an area which has been continuously occupied by the Karitiana for almost 50 years, with the group finally establishing permanent contact with the Brazilian federal indigenous agency (FUNAI) in the late 1960s (between 1967 and 1969). This led to ongoing complaints from the Karitiana, claiming that the number of prey animals has been decreasing sharply around the village, which in turn meant that hunters were moving farther and farther afield to find their prey.

Byyjyty ot'soop aky (literally "the hairs of Byyjyty:" Byyjyty was a demiurge who created the Karitiana in mythical times from locks of own hair), which in Portuguese is known as the Candeias River Village (aldeia), is located next to the São Sebastião waterfall, alongside this great right-bank tributary of the Madeira River. The village lies outside the Karitiana territory and was founded by the pajé Cizino Dantas Morais in 2002 as part of the group's strategy to recover the lands they traditionally occupied, and which were not included in the official federal demarcation process in 1978. In fact, the origins and history of the Karitiana lie in the Candeias River Valley and its right-bank tributaries, where the group lived until they were pushed westward in the 1960s (to where the Kyõwã village is currently located) by pioneer movements that have been sweeping across Rondônia since the late nineteenth century. The village is home to 30 inhabitants (2015), and is located within an area with abundant forest cover; the hunting prey is also abundant and easily found near the inhabited area. However, because the village is located outside the officially protected area, there is an ongoing harassment by fishermen and non-Indian hunters, as well as the employees of the farm to which the village's land actually belongs.

In both of the studied villages, as well as the other three that exist (Igarapé Preto, Bom Samaritano, and Rio Caracol), the indigenous families raise large numbers of chickens. I only observed ducks in Kyõwã during the time I spent there in 2006 and 2011. It should be mentioned, that my observations were also made among the Karitiana who were temporarily housed in the Casa do Índio, a type of shelter (in extremely precarious conditions) run by FUNAI alongside 
its installations in the urban area of Porto Velho. When Karitiana families move to the city, for whatever reason, they often bring some of their chickens with them (along with their other animals like dogs, cats, parrots, macaws, and monkeys). The birds spend their time scrounging through the grounds in the back of the building. Families who live in the city also usually keep chickens and other pet birds, such as parrots and parakeets, in their backyards.

The data discussed here were obtained through ethnographic field research, which combines observation of social practices and direct interaction with individuals. The fieldwork was carried out over 15 months, divided into periods ranging from one to six months between 2003 and 2015, in four of the five Karitiana villages (the Caracol village was only founded after my last trip to the field).

The native taxa which appear in this study were identified by observation of the animals while in the company of the Karitiana (mostly men) on walks in the woods, on the roads leading to the villages, and when the hunters returned from forays, as well as in the area surrounding the residential areas themselves. The "species" (or "tipos" ["types"], as the Karitiana call them) were identified (in a manner which was always provisional and certainly never a completely perfect match $^{4}$ ) using the works of Helmut Sick (1984) and Deodato Souza (1998, a pocket guide for identifying birds) as references, and also widely discussed with the Karitiana, who greatly appreciated the colorful drawings in that text. Most of the time, I was meeting with a group of individuals (ranging from two to eight in number) and showing them images of the birds, which led to long and productive discussions. Together, the interviews and group conversations involved approximately 30 Karitiana interlocutors, including men (the majority), women and even children, in order to obtain a wider-ranging and more accurate impression of the grou's ornithological knowledge. I should also point out that, in this article, I continue my efforts to combine Americanist ethnology with anthropological studies of human-animal relations, which include incorporating relevant biological discussions, so as to understand interactions between indigenous peoples and certain non-human beings. In mobilizing scientific zoological knowledge to investigate relations between the Karitiana and birds, I attempt to recognize the animals on their own terms, thus sharing the suggestion by Nicolás Careta (2001: 345, translated by the author) that animals are "beyond the limits of academics, too alive and too restless (...)." In this way I try to avoid a separation (which is very frequent in ethnology, anthrozoology or human-animal studies) between the animal as subject, agent, actant, or social being and the animal as a sign, symbol, emblem, allegory, or product of human cognition and meaning-making. Animals are both things at once (see Vander Velden 2017), and in my opinion, it is only by integrating these two analytical dimensions a fair multispecies ethnography (Kirksey and Helmreich 2010) can be produced.

\footnotetext{
${ }^{4}$ By this I mean that the notion of "species" as used in scientific zoology does not work the same way among the Karitiana, which means that the zoological species and the Karitiana "species" ("types") do not necessarily refer to the same "real" creature.
} 


\section{On chicken and other birds}

A large number of new beings - those we call animals ${ }^{5}$ - were introduced into everyday life of the Karitiana after contact with non-Indians. Contrary to many other indigenous societies in the Amazon, the Karitiana did not incorporate these beings into their mythical history, namely the corpus of narratives describing what they call tempo antigamente (roughly, "the olden times"). The new beings are only described as originating "from the hands of the whites," and "having no history" ("chickens have no history," for example), in the sense that they do not appear in the adventures involving humans, nonhumans, and the creator demiurges that took place at the beginning of the world the Karitiana know and inhabit today (and which can be confirmed in certain collections of myths designated as "histories;" see CIMI/RO 2006). The only exception - a newly introduced species that "has a history" - I found was a ground dove (rolinha, in Portuguese, doves in the Columbidae family) called opok tioky, which will be discussed later on in this text.

Consequently, the origins of dogs, domestic cats, horses, oxen, donkeys, goats, rabbits, and ducks, pigeons, and chickens are not part of the absolute past of myth, but rather the experience of some Karitiana elders (many of whom are still alive today) who remember their first childhood contact with these strange beings that accompanied the non-Indians who occupied their territory. For example, the shaman Cizino Karitiana recalls the first appearance of chickens:

The very first white man who appeared in the village of the Indians was called João Chave[s]. [It was] this man who brought the chicken to the Indians to breed in the village. That's how the Indians got to know chickens; in the language it was called opok ako. João Chave[s] brought a chicken to Antônio Morais to raise in the Karitiana village, and that is how chickens were raised in the Karitiana village ${ }^{6}$.

This information is confirmed by Epitácio Karitiana, who is thought to be around 60 years old today: "Chickens, [it was] also rubber tappers [on the Candeias River] who gave the Indians chicks that they raised."

\footnotetext{
${ }^{5}$ Like many other Amerindian languages, Karitiana lacks a word for "animal" that spans the wide variety of beings in the scientific (and popular) Western biological sense. In my opinion, there are two possibilities for translating this notion into Karitiana: kida or kinda is commonly translated as "beast" (bicho, in Portuguese) and generally refers to monstrous or dangerous beings (which we would classify as aggressive animals or supernatural beings) but can be glossed as "creature, being," and himo, literally "[hunted] meat," which normally applied to animals killed for food, but may occasionally also be used for animals in general. This term is sometimes adjectivized to describe beings whose flesh is not food, as in the case of him sara, or "bad meat" (and consequently "non-prey").

${ }^{6}$ This text was written by the young people Karitiana Walmir, Genilda, Marcos, Sarita, and Valdecir for a school activity that consisted of surveying the elders for information about first contact with the animals introduced along with contact with whites. I wish to thank Dirceu Orth for his assistance with this activity.
} 
So the domestic chicken (Gallus gallus domesticus, Linnaeus, 1758), which appears to be native to Southeast Asia and absent from the Americas until the arrival of Europeans in 1492 (Nordenskiöld, 1922: 1-13) ${ }^{7}$, is thought to have first been met by the Karitiana in the first half of the twentieth century, when they began to interact with rubber tappers who followed the rubber boom throughout the Candeias, Jamari, and Jaci-Paraná River Valleys, and tended to raise chickens where they lived. Several of the older Karitiana elders state that the practice was quickly adopted and appreciated by the group, as it appears to have been in other indigenous societies across South America (Nordenskiöld 1922: 1-13).

Like other Amerindian peoples, the Karitiana are familiar with a significant variety of wild birds that inhabit the forests of southwestern Amazonia ${ }^{8}$. Strictly speaking, there is no single term in the indigenous language for the entire class of birds, although some of my interlocutors offered the term ijo for birds "born in the bush" (nascidas no mato), i.e. native or wild birds. However, this categorization is not consensual: most individuals claim that the category ijo designates only small birds (usually Passeriformes). Size seems to be the defining criterion here, since several of my interlocutors expressed doubt about the inclusion of large birds, such as jaburus (Jabiru mycteria) and curassows (Cracidae), in this group. Ducks, macaws, hawks, parakeets, toucans, guans, and oropendolas may all be included, but not domestic chickens, which "are not born in the bush."

The sub-groups of birds also do not have a specific name, although the Karitiana seem to recognize (but not name) winged beings as a whole, as well as unnamed or covert subsets: they say that a certain bird is the same "kind" (tipo) as another one ("jeokon is a kind of toucan"), or they use expressions denoting consanguineal kinship ("jeokon's brother is keep") or non-kinship relations of identity ("ot'ot's companion/partner is boxipa"), similar to the use of kumpaji ("companions") by the Aguaruna in Peru (Jernigan \& Dauphine 2008). In this sense, the classification of winged beings among the Karitiana greatly resembles the overall model of folk taxonomies proposed by Brent Berlin (1992; see also Forth 2016) and others: there is a life form roughly corresponding to the group which scientific zoology calls birds, comprising a series of subordinate sets (folk-intermediates) that are usually not named but often defined by prototypical forms. These sets in turn include those beings which are related, recognized as "relatives" or as being "of the same type" (and which would be, according to ethnobiology, folk-specifics). Table I below outlines these unnamed but "related" groupings; I use the term "generic name" to refer to the fact that the Karitiana often use the name of a particular "species" to designate the set of "related" beings or those of the same "kind" or "type." Whether the "species" used to name the set is recognized as "typical"

\footnotetext{
${ }^{7}$ This topic is controversial, with some authors arguing that domesticated chickens were already present in South America before the arrival of Europeans in the fifteenth century (see Carter 1971; Menzies 2002; and Vander Velden 2012b).

${ }^{8}$ Inventories in two areas close to the Karitiana territory registered 163 (in the Jamari National Forest) and 220 (around the Samuel hydroelectric dam) bird species (see Fagundes de França, Lima \& Freitas 2011 and De Lucca et al. 2009, respectively). Inventories in four other areas in the same state of Rondônia identified 458 species (Olmos et al. 2011).
} 
or "special" in some way remains to be investigated. Furthermore, the use of these "generic names" seems to be strictly contextual and pragmatic: it is not a group name, but a selection of the name of a particular "species" (like a prototype) that refers to a set of species which are related, associated, or perceived to be similar.

I wish to note that this article is not ethno-ornithological in nature. I am an anthropologist, not an ethnobiologist, and I am not even comfortable with the use of the prefix ethno- when it is used to define knowledge outside of the modern sciences (critiques of this practice seem to emerge from the so-called "ontological turn", according to Henare, Holbraad \& Wastell 2007). For this reason, this small excursion into Karitiana ornithological knowledge is merely an outline, a tool for investigating the practical and symbolic incorporation of certain beings introduced after contact with non-Indians, and issues related to food consumption and taboos during current times of alleged scarce hunting and growing concerns about sovereignty and food security of human populations throughout the Amazon region.

Table I. Outline of Karitiana bird categories (or related groupings)

\begin{tabular}{|l|l|}
\hline \multicolumn{1}{|c|}{ Generic name } & \multicolumn{1}{c|}{ Birds } \\
\hline Ijo & Songbirds - Passeriformes \\
\hline Orojyt' & $\begin{array}{l}\text { Waterfowl (storks, sandpipers, herons, kingfishers, jabirus - } \\
\text { Ciconiiformes, Charadriiformes, Coraciiformes) }\end{array}$ \\
\hline Jeokon & Toucans, aracaris - Ramphastidae \\
\hline Pat' & Macaws - Psittacidae \\
\hline Yrypan & Woodpeckers - Picidae \\
\hline Kyky & $\begin{array}{l}\text { Ducks - Anseriformes (sometimes classified as waterfowl, } \\
\text { orojyt') }\end{array}$ \\
\hline Pomo & Tinamous - Tinamidae \\
\hline Pyyp pyyp & Nightjars- Caprimulgiformes \\
\hline Pytpỹr & Hawks, eagles - Falconiformes \\
\hline Akyry & Vultures - Cathartidae \\
\hline Pirija & Swallows - Hirundinidae \\
\hline Gy & Parrots - Psittacidae \\
\hline Irĩng & Parakeets - Psittacidae \\
\hline
\end{tabular}

(For more complete information, see Vander Velden 2012a).

Beyond the groupings described in the table above, an enormous variety of birds are not aggregated into sets, or, alternatively, comprise sets with a single member. These include some of the Karitiana's favorite birds to hunt, such

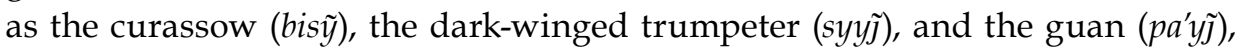
among many others which are recognized and named. A more in-depth study of Karitiana ornithological knowledge remains to be conducted, and here I offer 
only a glimpse to discuss the position of chickens, which have been introduced by white people.

As soon as the Karitiana encountered chickens, they integrated them into their grouping scheme according to the resemblance to known native birds. The late Antonio Paulo stated that "first, the Karitiana called the chicken pomo," a term for tinamous (Tinamidae); these birds are known to be tasty and the Karitiana recognize a large variety of these species". This was because "the chicken is like a tinamou," continued Antonio, registering the similarity between the birds according to Karitiana perception, and he added that "the old people explained that [chicken] was not tinamou." The association between chickens and tinamous from the outset indicated that new birds were edible, corroborating the classic suggestion by Mary Douglas (1966): only things which do not fit into well-defined categories are prohibited in terms of consumption, because they are the object of special symbolic interest.

But this scenario changed quickly. So, as Antonio Paulo Karitiana (who at the time of writing this paper was 50 years old) stated, the Karitiana soon recognized two fundamental differences between the hens introduced by the whites and the native tinamous. First, hens never leave homes and the company of people; in fact, domestic chickens only rarely go feral ${ }^{10}$. The Karitiana say the birds are "tame" (pyhoko, "mansas" in Portuguese) and therefore, unlike the birds of the forest, which people hunt and eat and generically call him papydna, literally "winged meat [prey]." Chickens are not meat or prey, since they are not hunted and do not have to be because they always live alongside humans, but they are almost never eaten (we will return to this aspect later). Additionally, chickens do not appear to be formally grouped with native birds, since "they are not born in the bush" being "from the bush" (gopidna, from gopit, "bush, forest") defines creatures that live outside villages, far from humans, and which generally avoid humans. Note that a contrast between "of the bush" (roughly "wild") and "of the home" (by'edna, "domestic") is also used to classify non-human beings among the Karitiana. The second major difference between chickens and native tinamous is that as soon as the former were adopted and protected by the Karitiana, the hens began to reproduce profusely within the villages. The animals that are kept in villages as wild pets usually don't breed, either because of their reduced numbers or other symbolic reasons, according to Cédric Yvinec (2005). This, consequently, is the main difference between chickens and the wild native birds kept as pets in the Karitiana villages: while the former reproduce freely, the latter, the eternal

\footnotetext{
${ }^{9}$ One variety (probably the white-throated tinamou, Tinamus guttatus) is called inhambu-galinha ("chicken-tinamou") in Portuguese (õhõrõra, in Karitiana).

${ }^{10}$ Studies on feral or feralized domestic fowl have investigated birds that have spent long periods of time without human contact. These show not only that the organization of domestic and feral birds is very similar, but also that feral birds quickly become accustomed to the presence of humans (McBride, Parer \& Foenander 1969: 145, 169). Carter (1971: 198) states that domestic chickens do not feralize; the absence of feral or wild flocks of these birds in the Americas confirms the introduction of only domestic strains of this species (which still exists in the wild in Southeast Asia).
} 
children (Yinec 2005), always remain small in number: in 2006 I counted 36 native birds ${ }^{11}$ raised in 17 homes in the Kyõwã village, an average of 2.1 birds per family. This number is high, but lags far behind chickens, of which each dwelling has dozens. For this reason, wild birds raised in the home are seen as individuals (many even have names), while chickens indicate (a non-named) multiplicity. Perhaps this is also why these introduced birds are not equated with other birds in Karitiana thinking and practices: because they seem to fully embody the suggestion by Lévi-Strauss that birds "form a community which is independent of our own but, precisely because of this independence, appears to us like another society, homologous to that in which we live" (Lévi-Strauss 1966: 204).

This exaggerated reproducibility soon made an indelible impact on how the Karitiana make sense of the domestic chicken, as a creature unlike native birds, and the way this species was incorporated into everyday life. The species name seems to have been inspired by its fertility: opok ako, most often translated by the Karitiana as "the many of the whites", in other words "things the white men have in great quantity", that which "accompanies whites" in significant numbers (opok, "whites," "non-Indians," and ako, "all," "many," "together"). Another possible translation of the term, offered by Marcelo Karitiana, is "together, to find others, to stay together," in a more comprehensive reading of the term opok in Portuguese referring to the "other" (and not just "other-white"). Marcelo explains that the name for chicken may have originated from the situation when, "in the past, the people saw the chickens all together." Among the Karitiana, chickens seem to have been perceived as they are among the Maya Q'eqchi' (Guatemala): foreign, since they were brought by non-Indians, they were "in constant contiguity" with them (Kockelman 2016: 53). Yet even if the species name does not refer to the white outsiders, it truly does still emphasize a unique characteristic of chickens that sets them apart from native wild birds: the fact that they always group into flocks that commonly contain large numbers. The name is even more intriguing because nothing that resembles the Amerindian way of naming imported chickens appears in Nordenskiöld's listing (1922: 13-46) of Amerindian terms for chickens introduced into South America.

The association between hens and excessive reproduction (in contrast with native animals, whether wild or domestic ${ }^{12}$ ) is reflected in the extent to which they are considered to be edible. The Karitiana claim that in the past they did not eat

\footnotetext{
${ }^{11}$ Considering the ornithological diversity of the region they inhabit, the Karitiana raise a limited variety of species: red macaws (Ara chloropterus), blue-and-gold macaws (Ara ararauna), Amazonian parrotlets (Nannopsittaca dachilleae, known in the region as curica), and Amazon parrots (Amazona sp), in addition to dark-winged trumpeters (Psophia viridis).

${ }^{12}$ Exceptions include dykysyko ants, which because of their numbers are used in a ritual for women who experience successive miscarriages and cannot conceive, as well as opossums (Didelphidae, dokõn, in the indigenous language), which are not considered edible as meat because they have many offspring and make the "woman who eats [them] have a lot of children," "get a lot of children, including twins." Opossum meat is even said to resemble chicken; childless couples can pull the teeth out of a slaughtered possum, roast and then powder them. This powder is mixed with coffee and drunk by the woman to make children come quickly.
} 
chickens, because if they did, the women would have many children, all as small as human fingers. In fact, even today, "there are a lot of chickens and a lot of eggs, and that's why a lot of chicks are born for no reason" (this is because of their eggs; sypi, "egg"; opok ako sypi, "chicken egg").

The Karitiana report that when the first chickens began to breed in the village, they ate five birds "to try, but [were] afraid they might die." Later hens were infrequently slaughtered for consumption, and Epitácio states that in the old days young people could not eat chicken eggs, since "hens have a lot of eggs and a lot of children," which would cause women to become pregnant time after time and have too many children. Even today, old Karitiana say that chicken eggshells shouldn't be stepped upon, because a man will impregnate his wife every time the couple has sex. As for the consumption of chicken eggs, even though today it is said they can be eaten, I believe it is rare: I myself have never seen a meal with eggs in the villages, and I suspect that the cakes some women bake to celebrate feasts are tough because they do not include eggs.

It is interesting to note that hen's eggs do not seem to be appreciated by numerous Amazonians or South American societies, which greatly enjoy turtle eggs, for example. Nordenskiöld (1922: 10) wrote that the South American Indians were not fond of eating eggs, quoting Jean de Léry, who reported that the Tupinambá considered eggs "poisonous." Nordenskiöld also cited reports from several authors stating that many native societies from lowland South America did not eat chicken eggs (10-11), although there are examples in certain regions of chicken egg being consumed and even preferred (Vander Velden 2012b: 128, notes 19-20). Carter (1971) argues that this widespread Amerindian refusal to slaughter and eat chickens is due to the fact that their feathers were used for decoration and to express symbolic values, and for ceremonial use, which - similarly to the treatment of such birds in Asia - supports the notion that chickens were introduced to the Americas prior to the arrival of Columbus. However, I am not aware of any evidence of this ritualization of roosters and chickens in the South American lowlands. Elsewhere (Vander Velden 2012b), I showed that even among the Portuguese colonizers in Brazil the meat of these birds was rarely consumed and generally reserved for the sick and to be eaten during celebrations. Finally, large-scale consumption of eggs and poultry certainly seems to be a recent phenomenon in contemporary industrial societies (Fiddes 1992), and the Karitiana, when they are in town, commonly obtain frozen or roasted chickens from markets and street vendors to feed their families away from home.

\section{They say they eat them, but they do not eat them}

Besides the hyperfertility they can provoke, chickens are not eaten for another reason: since they are always in the company of humans, chickens seem to have been incorporated by the Karitiana (as well as many other indigenous societies in lowland South America) into the category of familiar or familiarized 
animals (Fausto 1999), which the Karitiana call animais de criação in Portuguese, similar to what we would call pets or domesticated animals. Like dogs, cats, parrots, and macaws bred in the village houses or the surrounding areas, chickens are beings described as by'edna, a term the Karitiana translate as "raised" or "of the home," which the group relates to through the language of filiation: "chickens" (and all household animals), they say, "are like children." For this reason, the Karitiana do not eat chickens or their other pets, since this would be absurd, like killing and eating a son or a daughter.

As in other Amazonian societies, when they are asked, Karitiana individuals may say they eat their chickens, but in fact they do not. The possessive pronoun here is crucial: cooking one's own chickens seems impossible for any Karitiana, since people (especially women) seem to recognize the individuality of the flock that scratches in the yard. But one can apparently eat other chickens, or other people's chickens, whether these are purchased (live birds from neighbors, or frozen meat in urban supermarkets) or stolen (the subject of frequent accusations). A chicken could potentially (if very rarely) be slaughtered to make a meal with meat; in these very rare cases (I only saw two in 13 years of research), the birds are killed with weapons (usually bow and arrow) in something resembling the hunt on the outskirts of the village. What is familiar (domestic) must be defamiliarized to become prey (himo), and only then can these tame pets be converted into meat (himo) $)^{13}$.

Edibility is consequently not connected to "species" (or "types"), but rather to relationships. This explains why the Karitiana refuse to eat the animals they themselves have raised, like their chickens, but not chickens in general, i.e., those which are not theirs: people do not eat the chickens they raise (except in the extraordinary circumstances described above), but are not averse to eating chickens that belong to other people, whether stolen from the neighbor's henhouse, purchased fresh or frozen from urban supermarkets, or prepared in restaurants and at events, where chicken meat is served. Therefore, one could state that the degree of edibility of birds is connected to the nature of the personal relationship between the birds and the humans. Consequently, among the Karitiana there is a scale that separates the close/inedible from the distant/edible (meat). But at least in the case of chickens, this is not linked to species or "types" as in the industrialized Western world, in which chickens, pigs, and oxen are eaten, but dog and cat meat are taboo, since they are too close and to a certain extent, humanized (Leach 1964, Sahlins 1976) - but instead to the contextual proximity established between humans and nonhumans ${ }^{14}$.

${ }^{13}$ Vander Velden (2012) presents much more information on everyday relations with chickens in Karitiana villages. Note that the distancing of domesticated chickens with regard to their edibility contrasts sharply with how chickens are seen in contemporary industrial societies: they are considered stupid and raised, slaughtered, and consumed in numbers so ridiculously gigantic that they are no longer considered sentient beings but rather "food, even while still alive" (Potts \& Armstrong 2013: 152-154).

${ }^{14}$ Strictly speaking, the Karitiana also contrast between the edible and non-edible meat, based on "types" of beings: under no circumstances do the Karitiana eat dogs, cats, horses, or various 
This way of organizing the edibility of animals is common in the Amazon, where different beings within the same species can be killed and eaten when they live free in the forest, but immediately become taboo when they are raised as pets in human settlements (Erikson 1987, 1988a, 1988b, 2000). The same goes for the native wild birds that the Karitiana capture in the forest to raise in their homes: they are happy to hunt macaws, parrots, and other birds and willingly eat their meat, but killing and eating a bird of the same species raised at home is unthinkable, even though the Karitiana recognize, that it is the same "type" of being. What differentiates these birds is the relationship I consider quasi-kinship (because pets are "like children") established within the intimacy and closeness of homes with certain individuals, contextually.

Animals that are raised as pets are consequently not considered food or meat (himo). The meat of nearly all the birds that inhabit the forest in the region and are regularly the targets of Karitiana hunters is considered "clean" and "healthy," and with the exception of smaller birds (ijo), all edible: like monkeys, they are beings that live "up high" (in Portuguese, do alto), beings whose meat is most appreciated by the Karitiana in contrast to animals from "down below" (in Portuguese, do baixo), land animals which are the subject of various permanent or temporary food restrictions. The only set of birds that the Karitiana normally do not eat are aquatic species (orowyt') that spend most of their time in the water and feed on fish. The meat of these species is said to be cold, and if it is ingested, the freezing water can enter the vagina of a pregnant woman during sex and the cold can kill unborn children still in the womb. Furthermore, meat of these species is avoided because the legs of these birds are thin (magras) and can consequently cause weakness and laziness, leaving the person who has eaten the meat fraquinha, magrinha ("weak, lazy").

In any case, this way of relating to domestic chickens explains the reasons behind what can be called the relative success which the Karitiana have had raising birds (and other species). For many years, the Karitiana have continuously requested and received chickens to raise from the governmental and non-governmental agencies that support indigenous peoples in Brazil. In fact, according to one FUNAI agricultural technician (personal communication), the foundation's entire investment in animal husbandry in indigenous areas should be "in small animals" (mainly poultry), rather than cattle or pigs, as a way to solve problems, such as scarce hunting, about which the Karitiana have been complaining ever since I began my research among them in 2003. But these projects have generally been unsuccessful, because the Karitiana usually do not slaughter chickens for consumption. A poultry breeding project with "white hens from the farm," as the Karitiana call them, distinguishing them from the birds they keep loose in the villages, was a complete disaster: people say that all chickens trapped in a large chicken pen built in Kyowã died after "eating the guts"

forest beings (gopit, "of the forest"). But it seems that certain beings in the edible category can be transformed into non-edible by establishing close relationships (as is the case with pet pigs, for example). 
of each other ${ }^{15}$. Even though the chickens that the Karitiana occasionally receive from the government agencies and let roam free in the villages do multiply, they are seldom eaten. As a result, it seems that issues of game scarcity and food insecurity are not finding resolution in these simple animal husbandry projects. Gade (2015: 33) states that it is precisely this refusal to consume chickens, and especially their eggs, that caused populations of these birds to explode in various indigenous villages throughout the Americas. Hence what I call the "relative success" of projects or programs to introduce animal raising in Amerindian communities: the animals reproduce by default because they are not slaughtered and their eggs do not serve as food, and consequently, the abundance of these animals does not meet the objectives set for the projects (which have been underway in Brazil since at least eighteenth century), i.e. providing regular supply of food.

In his master's dissertation, André Martini (2008: 117-122) showed that a fish farming project implemented to feed several indigenous communities in the upper Rio Negro basin (near the Brazilian border with Colombia), where people had reported problems related to declining fish stocks, failed because by feeding the animals in line with the project guidelines, the women created strong ties of affiliation with them. The fish were inserted into the logic of consanguinity, which naturally prevented them from being caught and eaten; the fish were then sold by the men, who used their earnings to buy frozen chicken in nearby villages, always at exorbitant prices. Like the Karitiana, these indigenous peoples refused to eat beings which became "like children," in the words of the Karitiana, because of the care they received, especially after being fed by human (and female) hands, just like indigenous children. This situation extends beyond these two Amazonian populations - several studies have indicated problems of varying severity in animal husbandry activities in villages in Brazil and neighboring countries (see Vander Velden 2012a for a detailed discussion).

The chickens among the Karitiana are always roaming free, scrounging around family homes during the day, and gathering of their own accord in henhouses at night. These simple structures of wood and wire mesh are built by local families near their houses. People only need to close the henhouses up to protect the birds from attack by nocturnal predators, such as felines and opossums. Community chicken pens built by state agencies are systematically abandoned: during my last visit to the Byyjyty ot'soop aky village in July 2015, a huge chicken pen built by three men was crumbling from neglect. According to Meireles Karitiana, the chickens only slept there, and were set to roam free around the village during the day. Meireles added that initially - and according to the instructions received by the Karitiana - the chickens were kept cooped up, but were not fed because there was no corn, so they ended up being released.

\footnotetext{
${ }^{15}$ The focus on the birds' white plumage, their foreign origin, and their anomalous behavior may be related to the Karitiana's association between whiteness or pallor, death, and non-Indians, a topic I hope to explore in the future. The invariable whiteness of modern industrially-bred chickens also carries associations with indifference, invisibilization, and mass death, in contrast to the very visible and unpredictable coloring of "nature" (see Probyn-Rapsey 2013).
} 
These comments expose two other difficulties faced by animal husbandry projects in indigenous villages in the Amazon. The first is the fallacy of community projects in societies that organize production and distribution of food along familiar ties. The second challenge is the difficulty of feeding adult animals: in fact, while young animals are generally fed by their owners, adult animals should ideally "take care of themselves" (se virar, in Portuguese), in other words, find their own food. This aligns with the idea that these beings have a life cycle analogous to humans, with young people receiving care, protection, and nourishment, but growing into adults who are expected to be productive and at least provide for their own needs. The Karitiana, consequently, do not accept the obligation to feed confined adult animals, and the result has been the gradual abandonment of chicken coops or community pens.

As we have seen, animal husbandry (including raising of domestic chickens) does not seem to be the best solution to the perceived problems of food security and sovereignty of native peoples in Brazil.

\section{Ducks, doves and white herons}

Some other birds are recognized as "having no history," that is to say, they are nonexistent in the previous experience of the Karitiana (before contact with whites), and were only intentionally or unintentionally introduced after Karitiana encountered white people.

Domesticated ducks (which the Karitiana call "tame ducks," "city ducks," or "ducks that live on the water") were introduced by white people, and a few could be seen in Kyõwã in 2006: they all belonged to one woman (the late Dona Rosa), who bought them in the city and kept them near a stretch of the Sapoti Creek that passed behind her house. These ducks were given the same name as the native ducks (kyky), which became known as "bush ducks" (kyky gopipit) to differentiate them from the imported animals. There is also a native, wild duck the Karitiana call marreco in Portuguese (kykyj ina, literally "small duck"). Of another native bird they call oroj'yto (unidentified), they say "it is like a duck, it lives in water, eats fish." In Brazil, the Muscovy duck is called a bush duck (pato-do-mato) or wild duck (pato-selvagem or pato-bravo), because it is a native species, in order to differentiate it from the introduced species (Anas platyrhynchos) which is more commonly raised as a domesticated animal.

According to Epitácio Karitiana (Dona Rosa's husband), bush ducks are native to the area, but they were not bred or hunted for food. He stated that the ancestors of the Karitiana did not eat them, because their flesh "made a person's children become cold when disease attacked," or that "it was bad for newborns, who got cold." This latter comment reflects a common restriction on the consumption of other aquatic fish-eating birds, which are considered "cold." These waterfowl are almost never eaten (just like aquatic mammals, such as otters and giant otters), even today, because they live in the water "where it is cold," as the Karitiana 
say. If these animals are killed for food, they add, "cold water enters the woman's vagina when she is having sex and kills the child with cold, while it is still in the uterus."

Apparently, the Karitiana only began to eat the meat and eggs of these birds (and use their feathers in their crafts) after having encountered them, following contact, "among the whites." Therefore, it was the introduction of these tame ducks that seems to have made the previously scorned flesh of wild bush ducks edible. This is an interesting point because strictly speaking, native ducks and those introduced with the arrival of non-Indians are the same species: Cairina moschata, the Muscovy duck, which is native to neotropical America and was reportedly domesticated by various peoples in this region (Donkin 1989). For example, Guarani groups maintained "creole ducks" (Cairina moschata) in their villages to combat insect infestations (Angulo 1998). Although the Karitiana seem to recognize the same animal (since the same term kyky is used for wild and domestic birds), as with other introduced animals, they differentiate these ducks by the presence or absence of their association with humans and maintain that the native ducks did not live in the villages prior to contact. Perhaps in this case we can say that "in the hands of the whites" the Karitiana did not recognize the duck, specifically, but rather duck's domesticity. In fact, in Kyõwã they told me that the ducks there had been "bought in the city."

As for doves, there seems to be some confusion which may indicate that we are dealing with more than one species, or that the Karitiana at least recognize distinct varieties (tipos in Portuguese, types or kinds) of what they call pigeons or doves in Portuguese. What they call city doves, some (like the late Garcia Karitiana, for example) call $d y^{\prime} y$, and they are not and cannot be food. Others, like Epitácio, also say that the dove called opoktioky ("dove" or "little dove that lives over the trees," or pomba galega in Portuguese ${ }^{16}$ ) "did not exist here [in the village, in the region] in earlier times;" yet others claim that this species is native, but was given the same name as the synanthropic species introduced with the arrival of the whites. These doves also cannot be eaten.

The Karitiana may have associated exotic dove with various types of native birds known as teet (generically, "dove, pigeon"), ywin ("a bigger pigeon from the bush") and kyytsoop ("an even bigger pigeon"). They say that none of these can be eaten, because they cause "tiredness," except in the older people (who are already permanently "tired;" that is, short of breath). It is also said of all these birds that they cannot be eaten, injured, or even bothered: they are thought to have originated from the blood of a Karitiana group who in the past were killed by whites; another version recounts that "some time ago someone killed another Indian [opok pita, the name for neighboring and enemy indigenous groups], and this Indian said his blood would attract a lot of pale-vented pigeons. Then another Indian killed the old Karitiana, and his blood attracted a lot of pale-vented pigeons"

${ }_{16}$ The bird popularly known as pomba-galega or the pale-vented pigeon (Patagioenas cayennensis) is native to the Americas. 
(as narrated by Antonio Jose). These pigeons cannot be eaten, because if they were, "white men or another Indian would kill Karitiana". The name opoktioky itself literally means "white/other Indian (opok) killed me (tioky)". Even the native juriti (white-tipped dove, Leptopila verreauxi) "cannot be eaten, [because] white man kills". Furthermore, none of these species can be consumed in festas (literally, "feasts"), the rituals that the Karitiana periodically perform to ensure good health of the group and the abundance of game in the forests of the region.

Lastly, the Karitiana state that the white herons seen on the banks of the creeks in their territory (kendopok ôjeng) and the socó (probably the tiger-heron, ot'ot') did not exist in the area previously, and consequently "are not in the [indigenous] law". In other words, it is not clear whether they can or cannot be eaten. Nevertheless, some informants argued that these two birds were "related" (similar) to other aquatic birds, such as okori (the jabiru, Jabiru mycteria), owãnowãn ("a large bird like a jabiru," unidentified), and the boxipa ("heron-like", unidentified), among others (probably all Ciconiiformes). Like all species grouped as aquatic birds (orojyt'), white herons and tiger-herons should not be eaten because they are "cold", as we saw earlier, and also because they have thin legs ("they are thin"), and consequently provoke weakness and laziness, making the person who eats this meat "weak and emaciated."

One of the indications that these beings are strange and their origin exotic, from the Karitiana point of view, is the fact that their flesh cannot be consumed in the festa da caça (hunt feast, or him myyj), a ritual to generate "health" and "joy" in which a large quantity and variety of animals are hunted and eaten (preferably birds and monkeys, since they are from "up high," i.e. inhabit the skies or treetops and are associated with hawk or harpy-eagle). On the eve of the feast, all the village hunters head to the forest to bring in as much meat as possible, since an abundance of meat is needed for an appropriate, healthy, and joyful existence. Nevertheless, the meat of several species cannot be eaten on such occasions, for different reasons: they are said to be "not useful for the feast." This includes all the animals introduced by the whites, which are not permitted in these rituals, because these beings did not exist during the "time before [in other words, in the olden times], they were raised by whites, chickens, domesticated pigs, turkeys, ducks, goats," as I was told by cacique Francisco Delgado in 2003. Because the hunt feast is a "traditional" celebration, beings from outside, that are known to originate from the world with which the Karitiana had contact (often violent) only after the mid-nineteenth century, should not be present.

\section{Concluding remarks}

Birds that were introduced along with contact (intentionally, like chickens and ducks, or "accidentally," which seems to be the case of species such as pigeons and herons, which may be considered as invasive species in the region) are generally not eaten or considered food by the Karitiana: they are said to be "not good 
for food." The reasons why these birds are not considered himo, "prey/meat," vary. Because chickens are raised, they are considered to be "like children" or "like offspring," and are unlikely to go into the stew-pot: they cannot be meat because they are not game or prey animals (himo). Note, however, that this taboo related to consuming chickens is not absolute but rather relational: one's own chickens are not eaten, but eating those of others (stolen, purchased, frozen) is not a problem. Varieties of pigeons seem to be associated with violent penetration of the whites into the territory occupied by the Karitiana: they seem to be considered non-Indian humans (opok, "others," indicating alterity), perhaps because these anthropophilic birds begin to appear in the region in great numbers at the same time as the non-Indians who came to permanently settle there. Herons and ducks, despite their similarity (or "kinship," following the Karitiana classificatory logic) to native species, are not eaten, because, like many other birds and mammals, they inhabit aquatic environments that make their flesh "cold" and consequently dangerous for humans. Additionally, their exotic origin distinguishes them from the birds consumed in the traditional festivals that celebrate hunting as a way to attain health and joy.

It may well be that their association with non-Indians and white people (known to be "in the midst of the whites" or "through the hands of the whites") is the ultimate reason why the meat of these birds is not appreciated by the Karitiana, but this hypothesis still requires more profound investigation. It is curious, however, that many report often or occasionally eating these birds, which - while not ordinarily himo - can be called him sara, "bad meat," or him a y ki, which indicate that "it is a kind of meat for eating, but it is not eaten; it's meat, but you can't eat it. You want to eat it, but you can't." The Karitiana often point out that the meat of a particular animal shouldn't be eaten, but if the meat is "well seasoned" (bem temperadinha in Portuguese, particularly with salt, with which the Karitiana were not familiar prior to contact), it can be relatively safely consumed. Even so, my field experience demonstrates that this is not very common, and like many other indigenous peoples in lowland South American, the Karitiana report eating, but do not actually eat these kinds of meat, which for various reasons are truly considered bad, dangerous, and unfit for consumption. In any case, there is some variation in attitudes concerning food prohibitions (as well as knowledge of non-human beings in general), as highlighted by other authors who have studied (ethno-)ornithological knowledge (Bonta 2008: 3-4).

In conclusion, this scenario begs some questions. Are these exotic beings, both domesticated (chicken) and wild (or synanthropic), indelibly marked by their association with non-indigenous settlers, who are generally viewed negatively (and understandably so) by indigenous peoples as the agents of destruction and violation of native ways of life? Is this the case with domesticated species that are adopted by indigenous communities as household pets? Can we consider their association with non-Indians, and their exotic origins, as criteria for classifying these beings? And if so, should projects that encourage raising these species in the villages be treated as a preferred means of solving problems related 
to scarce prey and food sustainability and production (Vander Velden 2015)? For some time, the Karitiana have claimed that game is becoming scarce and more difficult to obtain in the area surrounding their villages; for this reason, they maintain, projects involving animal husbandry can be a solution to decreasing access to meat. As is the case among indigenous peoples in the Amazon in general, a meal without meat is incomplete; the Karitiana themselves say that a dish without meat is equivalent to "having nothing to eat" (Castro 2018: 267). But all experiments that consist in introducing systems of animal husbandry there have failed, as seems to have happened in many other documented cases (reviewed and discussed in Vander Velden 2012a). In this sense, the crucial question is: if hunting prey is becoming scarce, is raising animals a solution, considering that today (at least among the Karitiana) these animals are not even considered edible?

Of course, we are not talking here about an exercise in futurology: the Karitiana could revise their food taboos, as well as their ways of relating to non-human beings raised in their villages. These questions, however, should invite further studies on the animal species introduced into South American indigenous villages, whether domesticated or exotic, and/or invasive, and how these are inserted into the native taxonomies. We should attempt to understand how relationships can constitute classification systems - how domesticity and exotic origins in this case seem to position chickens and certain other exotic birds within the Karitiana classification of winged beings.

Attention to the technical aspects involved in introducing animal husbandry in indigenous villages is also necessary: the Karitiana often claim that raising animals doesn't work because they are not trained or instructed in how to relate to these foreign beings, which bring with them forms of relationship (such as confinement) that are also somehow alien to everyday indigenous life (cf. Vander Velden 2015). Despite the estrangement that separates exotic chickens in their multiplicity (whether raised in confinement or not) from the other beings with whom the Karitiana share the world, chickens are, at the same time, certainly a kind of pet, and for this reason are included in the everyday routines and affections of this group, particularly the women; in this way, I agree with Paul Kockelman's (2011) discussion of the the Q'eqchi' Maya (Guatemala), in which he recognized chicken as a particularly rich site for ethnographic research, because it is simultaneously self, alter, and object for its owners. This conclusion points to the complexity of the engagements between human communities and these very common birds. Along these lines, I hope this article acts as a reminder to ethnographers who express a common contempt for everyday objects, practices, and habits while in the field (as Joanna Overing pointed out), that the study of "universally overlooked" or "trivialized" birds like chickens may teach us a lot about the groups that keep them (Potts, 2013: 132-134), especially when they are exotic, introduced or non-native, i.e. novelties as curious and unusual as Christianity, airplanes, medicine, and anthropologists. 


\section{References}

Anderson, E. (2016). Birds of the Mongol Empire. Ethnobiology Letters, 7(1), 67-73.

Angulo, E. (1998). Interpretación biológica acerca de la domesticación del pato criollo (Cairina moschata). Bulletin de l'Institut Français d'Études Andines, 27(1), 17-40.

Belaunde, L.E. (1994). Parrots and oropendolas: The aesthetics of gender relations among the Airo-Pai of the Peruvian Amazon. Journal de la Société des Américanistes, 80(1), 95-111.

Berlin, B. (1992). Ethnobiological classification: Principles of categorization of plants and animals. Princeton: Princeton University Press.

Bonta, M. (2008). Valorizing the relationships between people and birds: Experiences and lessons from Honduras. Ornitologia Neotropical, 19 (Suppl.), 1-10.

Bulmer, R. (1967). Why is Cassoary is not a Bird? A problem of Zoological Taxonomy Among the Karam of the New Guinea Highlands. Man - New Series, 2(1), 5-25.

Carter, G. (1971). Pre-Columbian chickens in America. In: C. Riley, J.C. Kelley, C. Pennington \& R. Rands (eds.), Man across the sea: Problems of pre-Columbian contacts (p. 178-201). Austin: University of Texas Press.

Castro, A. de O. (2018). Koro'op: Emoções, sociabilidade, paisagem e temporalidade entre os Karitiana. Juiz de Fora, Brazil: PhD Thesis, Universidade Federal de Juiz de Fora.

CIMI/RO. (2006). Universo cultural Karitiana, volume I. Porto Velho: CIMI/RO.

Crocker, J.C. (1985). My brother the parrot. In: G. Urton (ed.), Animal myths and metaphors in South America (p. 13-47). Salt Lake City: University of Utah Press.

De Luca, A.C., Develey, P.F., Bencke, G.A., Goerck, J.M. (eds.). (2009). Áreas importantes para a conservação das aves no brasil. Parte II - Amazônia, Cerrado e Pantanal. São Paulo: SAVE Brasil.

Donkin, R.A. (1989). The Muscovy Duck, Cairina moschata domestica: Origins, dispersal, and associated aspects of the geography of domestication. Rotterdam/Brookfield: A.A. Balkema.

Douglas, M. (1966). Purity and danger: An analysis of concepts of pollution and taboo. London: Routledge.

Erikson, P. (1987). De l'apprivoisement à l'approvisionnement: Chasse, alliance et familiarization em Amazonie amérindienne. Techniques et Cultures, 9 (n.s.), 105-140.

Erikson, P. (1988a). Apprivoisement et habitat chez les amerindiens Matis (langue Pano, Amazonas, Brésil). Anthropozoologica, 9, 25-35.

Erikson, P. (1988b). Choix des proies, choix des armes et gestion du gibier chez les Matis et d'autres amérindiens d'Amazonie. Anthropozoologica, second numéro spécial, 211-220.

Erikson, P. (2000). The social significance of pet keeping among Amazonian Indians. In: A. Podbersceck; E. S. Paul \& J.Serpell (eds.), Companion animals and us (p. 7-26). Cambridge: Cambridge University Press.

Fagundes de França, D., Lima, E., de Freitas, M.A. (2011). Listagem preliminar das aves de bordas de mata e áreas degradadas da Floresta Nacional do Jamari, Itapoã do Oeste, Rondônia, Brasil. Atualidades Ornitológicas, 164, 51-56.

Fausto, C. (1999). Of enemies and pets: Warfare and shamanism in Amazonia. American Ethnologist, 26(4), 933-956.

Fiddes, N. (1992). Meat: A natural symbol. London: Routledge.

Forth, G. (2004). Nage birds: Classification and symbolism among an eastern Indonesian people. London: Routledge.

Forth, G. (2016). Why the porcupine is not a bird: Explorations in the folk zoology of an eastern Indonesian people. Toronto: University of Toronto Press. 
Gade, D. (2015). Particularizing the Columbian exchange: Old World biota to Peru. Journal of Historical Geography, 48, 26-35.

Geertz, C. (1973). The interpretation of cultures. New York: Basic Books.

Giannini, I. (1991). A ave resgatada: 'a impossiilidade da leveza do ser'. São Paulo: Master's Dissertation, Universidade de São Paulo.

Hunn, E. (1977). Tzeltal folk zoology: The classification of discontinuities of nature. New York: Academic Press.

IMOPEC (2011). Aves do território Tapeba. Fortaleza: Imopec.

Jensen, A. (1988). Sistemas indígenas de classificação de aves: Aspectos comparativos, ecológicos e evolutivos. Belém: MPEG (Coleção Eduardo Galvão).

Jernigan, K. (2016). Beings of a feather: Learning about the lives of birds with Amazonian peoples. Ethnobiology Letters, 7(2), 41-47.

Jernigan, K., Dauphine, N. (2008). Aguaruna knowledge of bird foraging ecology: A comparison with scientific data. Ethnobotany Research and Application, 6, 93-106.

Leach, E. (1964). Anthropological aspects of language: Animal categories and verbal abuse. In: E.H. Lenneberg (ed.), New directions in the study of language (pp. 23-63). Cambridge: MIT Press.

Lévi-Strauss, C. (1966). The savage mind. London: Weidenfeld \& Nicolson.

Kirksey, S.E., Helmreich, S. (2010). The emergence of multispecies ethnography. Cultural Anthropology, 25(4), 545-576.

Kockelman, P. (2011). A Mayan ontology of poultry: Selfhood, affect, animals, and ethnography. Language in Society, 40, 427-454.

Kockelman, P. (2016). The chicken and the quetzal: Incommensurate ontologies and portable values in Guatemala's cloud forest. Durham: Duke University Press.

Majnep, S., Bulmer, R. (1977). Birds of my Kalam country. Auckland: Auckland University Press.

Martínez Mauri, M. (2014). La etno-ornitologia al servicio de las aves. Turistas y habitantes de Guna Yala, Panamá. In: M.A. Vásquez-Dávila (ed.), Aves, personas y culturas: Estudios de etno-ornitologia, vol. 1 (p. 299-308). Oaxaca: CONACYT/ITVO/Carteles Editores/ $\mathrm{UTCH}$.

Martini, A. L. (2008). Filhos do homem: A introdução da piscicultura entre populações indigenas no povoado de Iauarete, rio Uaupés. Master's Dissertation, Universidade Estadual de Campinas, Campinas, Brazil.

McBride, G., Parer, I. P., Foenander, F. (1969). The social organization and behaviour of the feral domestic fowl. Animal Behavior Monographs, vol. 2, part 3, 125-181.

Menzies, G. (2002). 1421 - O ano em que a China descobriu o mundo. Rio de Janeiro: Bertrand Brasil.

Nemo, F., Grenand, F., Grenand, P., Cristinoi, A. (2017). Etnosemântica das classificações animais - exemplos de algumas línguas amazônicas. In: G. Marchand, F., Vander Velden, (eds.). Olhares cruzados sobre as relações entre humanos e animais silvestres na Amazônia (p. 299-319). Manaus: EDUA.

Nelson, R. (1983). Make prayers for to the raven: A Koyukon view of the northern forest. Chicago: University of Chicago Press.

Nicolás Careta, M.A. (2001). Fauna mexica: naturaleza y simbolismo. Leiden: CNWS Publications.

Nordenskiöld, E. (1922). Deductions suggested by the geographical distribution of some post-Columbian words used by the Indians of South America. Göteburg: Elanders Boktryckeri Aktiebolag. 
Olmos, F., Silveira, L.F., Benedicto, G. (2011). A contribution to the ornithology of Rondônia, southwest of the Brazilian Amazon. Revista Brasileira de Ornitologia, 19(2), 200-229.

Overing, J. (2003). In praise of the everyday: Trust and the art of social living in an Amazonian community. Ethnos, 68(3), 293-316.

Píno Benítez, N. (2014). Cosmovisión y aprovechamiento de las aves en el noroccidente de Colombia. In: M.A. Vásquez-Dávila (ed.), Aves, personas y culturas: Estudios de etno-ornitologia, vol. 1. (p. 309-318). Oaxaca: CONACYT/ITVO/Carteles Editores/UTCH.

Potts, A. (2013). Exotic familiars. In: A. Potts, P. Armstrong \& D. Brown, A New Zealand book of beasts: Animals in our culture, history and everyday life (p. 122-135). Auckland: Auckland University Press.

Potts, A., Armstrong, P. (2013). Picturing cruelty: Chicken advocacy and visual culture. In: J. Johnston, F. Probyn-Rapsey, F. (eds.), Animal death (p. 151-168). Sidney: Sidney University Press.

Probyn-Rapsey, F. (2013). Nothing to see - something to see: White animals and exceptional life/death. In: J. Johnston, F. Probyn-Rapsey (eds.), Animal death (p. 239-252). Sidney: Sidney University Press.

Reina, R., Kensinger, K. (1991). The gift of birds: Featherworking of native South American peoples. Philadelphia: University of Pennsylvania Press.

Rondon, C.M. da S. (1907). Commissão de Linhas Telegraphicas Estrategicas de Matto Grosso ao Amazonas. Relatório apresentado à Directoria Geral dos Trabalhadores e à Divisão de Engenharia (G.S.) do Departamento de Guerra. v. 1, Estudos e Reconhecimento. Rio de Janeiro: Papelaria Luiz Macedo.

Sahlins, M. (1976). La pensée bourgoise: Western society as culture. In: Culture and practical reason (p. 166-179). Chicago: University of Chicago Press.

Sanchez, G. (2019). Os Kujubim e os bichos: Uma etnografia multispecífica das relações entre humanos e não humanos no vale do Guaporé, Rondônia. Master's Thesis, Universidade Federal de São Carlos, São Carlos, Brazil.

Sick, H. (1984). Ornitologia brasileira. Rio de Janeiro: Nova Fronteira.

Souza, D. (1998). Todas as aves do Brasil. São Paulo: Editora Dall.

Tidemann, S., Gosler, A. (eds.) (2010). Ethnornithology: Birds, indigenous peoples, culture and society. London: Earthscan.

Vander Velden, F. (2012a). Inquietas companhias: Sobre os animais de criação entre os Karitiana. São Paulo: Alameda Casa Editorial.

Vander Velden, F. (2012b). As galinhas incontáveis: Tupis, europeus e aves domésticas na conquista do Brasil. Journal de la Société des Américanistes, 98(2), 97-140.

Vander Velden, F. (2014). Entre o Ji-Paraná e o Amazonas: Notas (e hipóteses) sobre o tempo antigamente dos Karitiana. In: F.F. Ferreira da Costa, J.V. Franco Neto (eds.), Multiverso indígena: Cultura, língua e educação (pp. 19-52). Salvador: EGBA.

Vander Velden, F. (2015). Dessas galinhas brancas, de granja: Ciência, técnica e conhecimento local nos equívocos da criação de animais entre os Karitiana (RO). CADECS Cadernos Eletrônicos de Ciências Sociais, 3(1), 11-34.

Vander Velden, F. (2017). Introdução ao Dossiê. R@U - Revista de Antropologia da UFSCAR 7: 7-16.

Walker, H. (2010). Soulful voices: Birds, language and prophecy in Amazonia. Tipití: Journal of the Society for the Anthropology of Lowland South America, 8(1), 1-21.

Yvinec, C. (2005). Que dissent les tapirs? De la communication avec les non-humains en Amazonie. Journal de la Société des Américanistes, 91(1), 41-70. 


\section{SUMMARY}

Things that white men have in great quantity: chickens and other exotic birds among the Karitiana (Rondônia, Brazilian Amazon)

This article discusses the inclusion of domestic chicken (Gallus gallus domesticus, Linnaeus 1758) and other exotic bird species as part of the knowledge and practices related to birds (an ethnoornithology) among the Karitiana, a Tupi-Arikém-speaking indigenous people in the northern part of the state of Rondônia, in the southwestern Brazilian Amazon. Chickens are believed to have been introduced to the Amazon basin after contact with non-indigenous population, although this claim is controversial. They were initially associated with certain native birds. However, certain remarkable characteristics of these birds soon sparked reflection through which the species was gradually distinguished from the birds of the forest. These reflections influence how the Karitiana currently relate to chickens, which includes raising them in the villages, a practice encouraged by public policies related to food production, security, and sovereignty.

Key words: chicken - Karitiana - Amazon - husbandry - ethnoornithology 